\title{
Study of Caffeine-Loaded Gelatin Nanoparticles for Treatment of Melanoma and Fibroblast Cells
}

\author{
Pei-Ru Chen ${ }^{1}$, Yun-Ju Chuang 1,*(D) \\ 1 Department of Biomedical Engineering, Ming Chuan University, Taiwan, R.O.C \\ * Correspondence: yjchuang @ mail.mcu.edu.tw (Y.-J.C.);
}

Scopus Author ID 7202686959

Received: 31.08.2021; Revised: 18.10.2021; Accepted: 22.10.2021; Published: 19.12.2021

\begin{abstract}
In this work, we aimed to study the effect of caffeine-loaded gelatin nanoparticles on melanoma cells and fibroblast cells. The B16F10 murine melanoma cells and L929 fibroblast cells were treated with a different dilution ratio of caffeine-loaded gelatin nanoparticles for 24, 48, and $72 \mathrm{~h}$. The cell assay results showed that treatment with caffeine-loaded gelatin nanoparticles (25\% and $50 \%)$ effectively inhibited the proliferation, viability, and migration ability of B16F10 melanoma cells at 48 and $72 \mathrm{~h}$. Moreover, we also found that the cell apoptosis of B16F10 melanoma cells was induced by treatment of 12.5, 25, and $50 \%$ caffeine-loaded gelatin nanoparticles. In the meantime, for L929 fibroblast cells, there was no significant cell cytotoxic effects observed with identical treatment. In summary, the caffeine-loaded gelatin nanoparticles induced apoptotic process inhibited cell viability and migration ability of melanoma cells and could be an alternative therapy for melanoma cancer.
\end{abstract}

Keywords: caffeine; gelatin; nanoparticles; melanoma cell.

(C) 2020 by the authors. This article is an open-access article distributed under the terms and conditions of the Creative Commons Attribution (CC BY) license (https://creativecommons.org/licenses/by/4.0/).

\section{Introduction}

Cutaneous malignant melanoma is one of the aggressive and deadliest forms of skin malignancy because of its high mutation rate and metastatic potential [1]. The incidence of malignant melanoma worldwide was estimated at approximately 324675 diagnosed new cases, and the mortality was estimated to be $17.6 \%$ in 2020 [2]. Incidence rates of diagnostic new melanoma cases are increasing by $1.5 \%$ per year, and mortality rates are reduced by an average of $1.2 \%$ per year over the past decade [2]. Melanoma is the major cause of death from skin cancer. For the early stage of melanoma, the effective cure method is surgery to remove the tumor. But for the advanced stage of melanoma, the surgical method shows poor treatment results, and the five years survival rate is as low as only $16.6 \%$. Currently, the most effective treatment of melanoma is chemotherapy. The elimination of melanoma cancer cells through apoptotic processes is the main approach of anticancer chemotherapies. However, melanoma cancer cells show a relatively lower apoptotic rate than other cancer cells under treatment of chemotherapeutic drugs and result in high drug resistance to chemotherapy [3-5]. Therefore, it is necessary to find alternative approaches to treat melanoma cancer besides surgery and chemotherapy.

In addition to surgical treatment and chemotherapy, cold atmospheric pressure plasmas (CAPs) have been shown to inhibit the development of cancer cells effectively and suggested as an alternative and innovative treatment approaches for anticancer therapy, including carcinoma [6, 7], melanoma cancer tumors [8-10] and other cancers [11-18]. Plasma, the fourth 
state of matter, consists of gas ions, free electrons, photons, neutral gas molecules, radicals, and exciting gas molecules. Plasma can be generated artificially by heating a neutral gas or applying an electromagnetic energy field to ionize or dissociate neutral gas molecules to cause the generation of reactive species mixture [19-21]. The cold atmospheric plasma is a nonthermal, near room temperature plasma operated in an atmospheric environment and mainly contains reactive oxygen species (ROS) and reactive nitrogen species (RNS) [22]. The ROS/RNS will damage the antioxidant system and DNA and subsequently induce apoptosis or necrosis, resulting in the death of cancer cells [23-26]. The ROS/RNS generated in CAP show less cytotoxic effect on normal cells [17], so that CAP treatment shows its promising anticancer approach. The CAP plasma jet was directly applied onto tumor tissues in most CAP treatment therapy. Unfortunately, the direct CAP plasma jet can only have a therapeutic effect on the few exterior cell layers of tumor tissues. And also, the CAP treatment therapy was limited to apply on skin tumors or as an anticancer supplement during surgical operation [27, 28].

Recent epidemiological studies have indicated that coffee consumption is associated with decreased incidence of skin cancers, including melanoma [29]. According to the results, caffeinated coffee shows a significant association in statistics but not for decaffeinated coffee. Caffeine, a main component of coffee, is a natural methylxanthine alkaloid and central nervous system (CNS) stimulant. It has been shown that caffeine can inhibit proliferation and induce apoptosis of tumor cells [30, 31]. In animal experiments, caffeine has been shown to enhance antitumor immune response [32] and inhibit the invasiveness and metastasis of cancer cells $[33,34]$.

Therefore, the present study is aimed to explore the anticancer effect of caffeine-loaded gelatin nanoparticles. B16F10 melanoma cells and L929 fibroblast cells are exposed to caffeine-loaded gelatin nanoparticles. Then the cell viability, cell migration rate, caffeine release rate, immunofluorescence staining, and calcium deposition staining of apoptotic cells are determined in vitro to verify the effect and possible mechanisms of caffeine released gelatin nanoparticles treatment melanoma cancer cells and normal fibroblast cells.

\section{Materials and Methods}

\subsection{Preparation of caffeine-loaded gelatin nanoparticles.}

A two-step desolvation method was used to manufacture caffeine-loaded gelatin nanoparticles [35]. Gelatin of $0.20 \mathrm{~g}$ was dissolved in $10 \mathrm{ml}$ distilled water under the constant heating temperature of $40{ }^{\circ} \mathrm{C}$. Acetone solution was used as a desolvating agent to precipitate the gelatin. $10 \mathrm{~mL}$ acetone was added to the gelatin solution, and the supernatant solution was discarded. The remaining sediment gelatin was re-dissolved by adding $10 \mathrm{~mL}$ distilled water and stirred under the temperature of $40^{\circ} \mathrm{C}$, and $0.1 \mathrm{~g}$ caffeine was added and stirred to dissolve completely. The $\mathrm{pH}$ of the gelatin solution was adjusted to values of 2.5 . Then $25 \mathrm{~mL}$ acetone was added drop wisely to desolvate the gelatin solution again and to form the gelatin nanoparticles. After that, $1.5 \mathrm{~mL}$ of $0.5 \%$ glutaraldehyde solution was added and stirred for 12 hours for cross-linking caffeine-loaded gelatin nanoparticles. The remaining solvent, acetone solution, was removed using a vacuum evaporator. The final resultant caffeine-loaded gelatin nanoparticle solution was stored at $4^{\circ} \mathrm{C}$ for the following experiments. 


\subsection{Cell line and cell culture.}

The murine melanoma cell line B16F10 and fibroblast cell line L929, obtained from Culture Collection and Research Center (Hsinchu, Taiwan), were used for the following studies on the effect of caffeine. Dulbecco's modified Eagle medium (DMEM) containing $10 \%$ fetal bovine serum (FBS), $100 \mathrm{U} / \mathrm{ml}$ penicillin, $100 \mu \mathrm{g} / \mathrm{ml}$ streptomycin, and $10 \mathrm{mM}$ HEPES buffer was used as a culture medium for both B16F10 and L929 cells. The B16F10 and L929 cells were grown in cell culture flasks and incubated in an atmosphere of $5 \% \mathrm{CO}_{2}$ and $100 \%$ relative humidity at a temperature of $37^{\circ} \mathrm{C}$ and subcultured every three days.

\subsection{Cell viability assay.}

The caffeine effect on cell viability of B16F10 and L929 cells was determined by using a colorimetric assay, MTT (3-(4, 5-dimethylthiazol-2-yl)-2, 5-diphenyltetrazolium bromide), to detect the activity of mitochondria in cells. B16F10 and L929 cells were cultured in 96 well plates at a density of 10000 cells per well. Caffeine-loaded gelatin nanoparticles diluted with different dilution ratio $(50 \%, 25 \%, 12.5 \%$, and $6.25 \%)$ was added into each well for $24 \mathrm{~h}, 48$ $\mathrm{h}$, and $72 \mathrm{~h}$ incubation. After incubation, $200 \mu \mathrm{l}$ MTT solution was added to each well and incubated for another $3 \mathrm{~h}$ in the dark. Then, $200 \mu \mathrm{l}$ dimethyl sulfoxide (DMSO) solution was added to the well to dissolve insoluble purple formazan crystals into a colored solution. The absorbance of the colored solution at $570 \mathrm{~nm}$ was analyzed by using an automated microplate spectrometer.

\subsection{Cell apoptosis assay.}

In order to investigate the apoptotic effect of caffeine-loaded gelatin nanoparticles, Hoechst 33342 staining was performed. It is a fluorescent stain for labeling DNA in fluorescence microscopy, also commonly used to visualize nuclei. By Hoechst 33342 stain, the nuclear morphology such as condensation or cleavage, which is a symptom of apoptosis, can be observed. After cells were seeding in a 96-well plate for adhesion, we treated B16F10 and L629 cells with caffeine-loaded gelatin nanoparticles. Then culture medium was removed, and the cells were washed by PBS buffer solution two times. Cells were fixed for $20 \mathrm{~min}$ in $4 \%$ formaldehyde, and then formaldehyde was removed. After washing with PBS two times, cells were stained with Hoechst for 30 min. Finally, fluorescent images of cell nuclei stained with Hoechst 33342 were obtained by fluorescence microscope at $461 \mathrm{~nm}$.

\subsection{Alizarin red assay.}

The Alizarin red assay was performed to determine the degree of cell calcification by colorimetry qualitatively. The procedure of the Alizarin red assay was stated as follows. The B16F10 and L929 cells were cultured in 24 well plates with a density of 10000 cells per well. Caffeine-loaded gelatin nanoparticles diluted with different dilution ratio (50\%, 25\%, 12.5\%, and $6.25 \%$ ) was added into each well for $24 \mathrm{~h}, 48 \mathrm{~h}$, and $72 \mathrm{~h}$ incubation. After incubation, the culture medium with caffeine-loaded gelatin nanoparticles was discarded, and the cells were washed gently three times using PBS buffer solution. Then, the B16F10 and L929 cells were fixed using $4 \%$ formaldehyde for $15 \mathrm{~min}$ and then removed formaldehyde. After washing with PBS buffer solution two times, $1 \mathrm{ml}$ of $20 \mathrm{mM}$ ARS was added into each well for $20 \mathrm{~min}$ at 
room temperature. Finally, the cells were washed two times with PBS buffer solution to remove ARS dye and then observed and recorded with a microscope.

\subsection{Cell migration assays.}

The cell migration assays were performed by utilizing a micropipette to scratch the plate's cell monolayer, resulting in a defined gap. First, 10000 B16F10 and L929 cells were seeded into 24 well plates for $24 \mathrm{~h}$ at $37{ }^{\circ} \mathrm{C}$ and $5 \% \mathrm{CO}_{2}$. An artificial wound on cell monolayer per well was made through scratching by a sterile plastic $1000 \mu \mathrm{l}$ micropipette tip and the resulting artificial wound gap was about $1000 \mu \mathrm{m}$. Then, caffeine-loaded gelatin nanoparticles diluted with different dilution ratio $(50 \%, 25 \%, 12.5 \%$, and $6.25 \%)$ was added into each well for $24 \mathrm{~h}, 48 \mathrm{~h}$, and $72 \mathrm{~h}$ incubation. The migration of cells and closure of the gap were observed and recorded by microscope after cell treatment with caffeine-loaded gelatin nanoparticles. The obtained images were used to analyze the cell gap closure area ratio by free imaging processing software, ImageJ.

\section{Results and Discussion}

In this research, the caffeine-loaded gelatin nanoparticles were prepared by a two-step desolvation method, and the resulting gelatin nanoparticles were affected by different types of gelatin and solvent [36]. The caffeine-loaded gelatin nanoparticles' size and distribution were determined by a particle size analyzer. The results of nanoparticles size and distribution from particle size analyzer are shown in Figure 1. The size distribution of gelatin nanoparticles formed by two-step desolvation is normal distribution-like and ranges between 480 and 870 $\mathrm{nm}$. More than $76 \%$ of gelatin nanoparticles have diameters ranging from 540 to $680 \mathrm{~nm}$. 9 $\%$ of the gelatin nanoparticles are $479.6 \mathrm{~nm}$ in diameter, and the other $15 \%$ are in the range of 772.4 and $870.1 \mathrm{~nm}$.

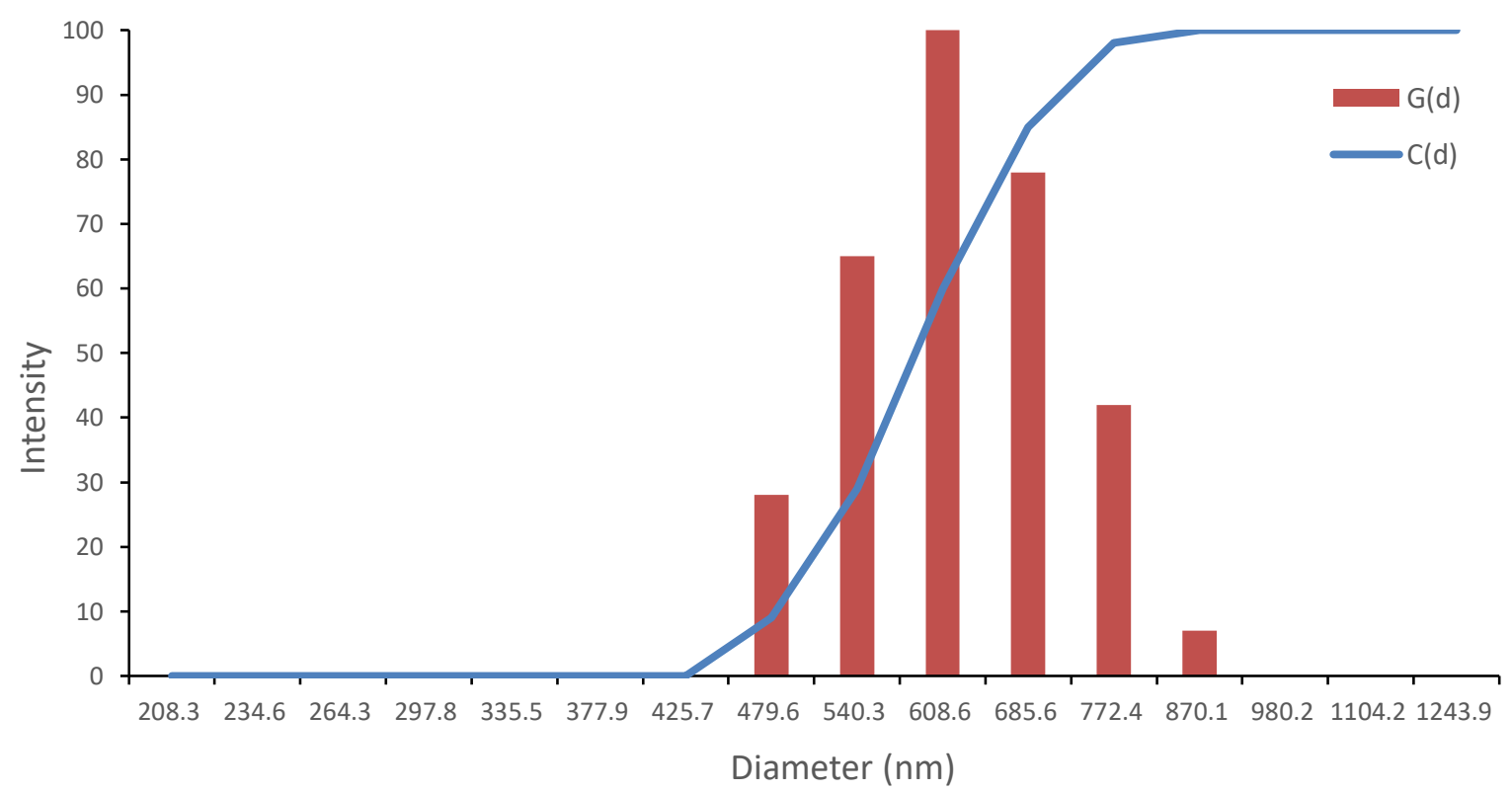

Figure 1. Size distribution of caffeine-loaded gelatin nanoparticles.

The dispersive diameter distribution of gelatin nanoparticles causes the degradation time of gelatin nanoparticles to vary with the diameter of nanoparticles and the release rate of 
caffein loaded in gelatin nanoparticles. The released rate of caffein from caffeine-loaded gelatin nanoparticles is shown in Figure 2.

The results show that the release curve of caffeine from caffeine-loaded gelatin nanoparticles can be divided into three stages. In the first stage, 0 to $12 \mathrm{~h}$, the release rate, 0.166 $\mathrm{mg} / \mathrm{mL}-\mathrm{h}$, is relatively higher than the other two stages.

In the second stage, 12 to $48 \mathrm{~h}$, the release rate is $0.044 \mathrm{mg} / \mathrm{mL}-\mathrm{h}$, and in the third stage, 48 to $168 \mathrm{~h}$, the release rate is $0.004 \mathrm{mg} / \mathrm{mL}-\mathrm{h}$. The highest release rate in the first stage can be attributed to the higher degradation rate of gelatin nanoparticles with a smaller diameter. The smaller nanoparticles have a higher surface-to-volume ratio and hence the degradation rate. Such dispersive size distribution of caffeine-loaded gelatin nanoparticles can prolong the release duration up to more than $72 \mathrm{~h}$.

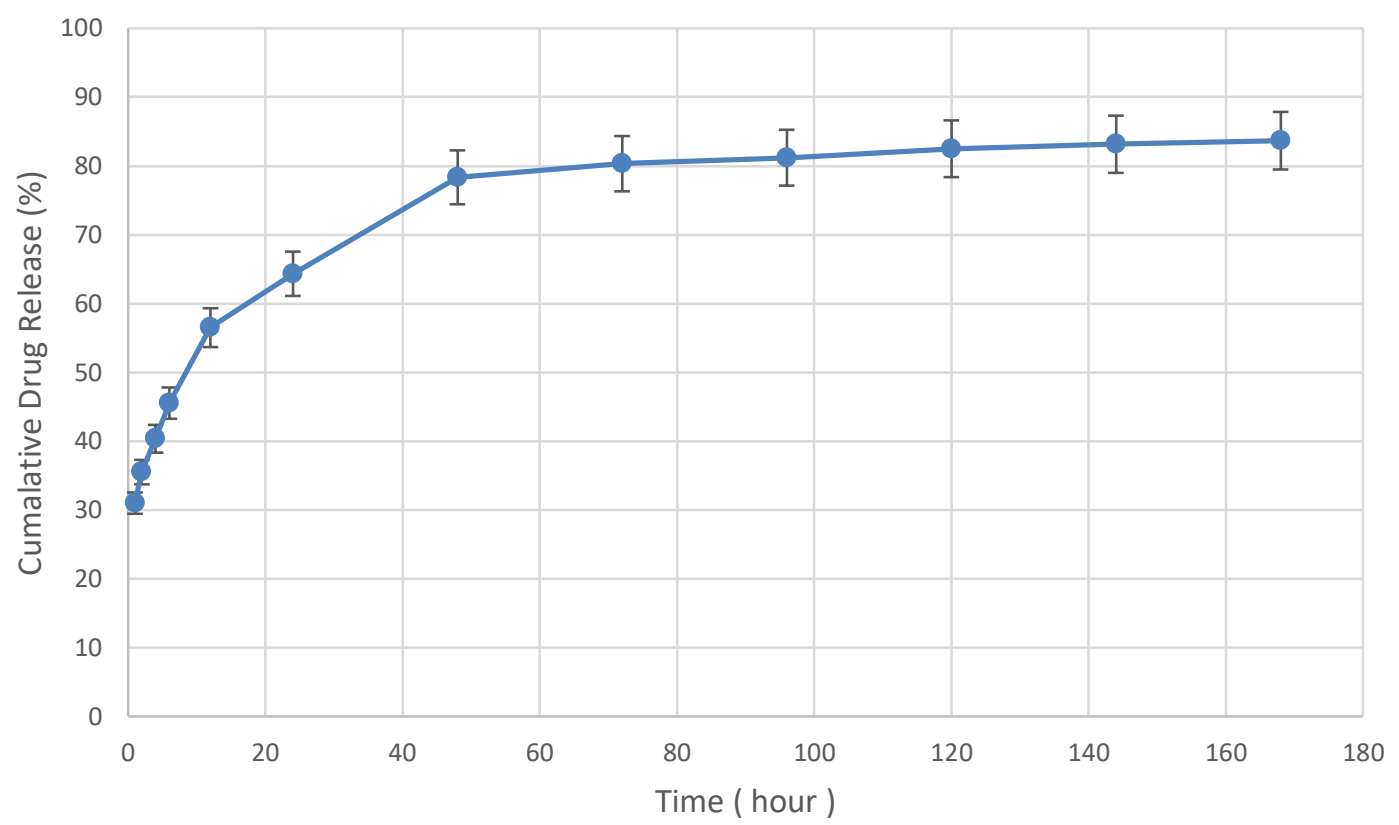

Figure 2. Caffein release curve from caffeine-loaded gelatin nanoparticles.

In order to understand the impact of caffeine released from gelatin nanoparticles on the B16F10 and L929 cells, the MTT assay was performed to determine cell viability under the same treatment as a function of different dilution ratios caffeine-loaded gelatin nanoparticles. The MTT assay was used to detect the metabolic activity of mitochondria in cells and used as an indicator of cell viability or proliferation. The dehydrogenase enzyme in mitochondria of viable cells reduces tetrazolium salt to insoluble formazan. The insoluble formazan crystals are dissolved using DMSO solution, and the resulting-colored solution is quantified by measuring absorbance at $570 \mathrm{~nm}$ using a microplate spectrophotometer. The greater the OD value, the greater the number of viable and highly metabolic active cells. The cell viability result is shown in Figure 3. The OD value is normalized to be 1 for each control group after $24 \mathrm{~h}$ incubation. Figure 3a shows the viability result of B16F10 cells. It can be found that the cell viability is decreasing with increasing the concentration of caffeine-loaded gelatin nanoparticles compared with the control group. The OD value does not significantly change after $24 \mathrm{~h}$ incubation for each dilution ratio of nanoparticles. For incubation of 48 and $72 \mathrm{~h}$, the cell viability with the treatment of 6.25 and $12.5 \%$ caffeine-loaded gelatin nanoparticles does not have significant change compared with $24 \mathrm{~h}$ incubation but decreases significantly for the treatment with 25 and $50 \%$. There is a similar response trend can be found in the viability of L929 cells. For L929 cells, the OD value with the treatment of 6.25 and $12.5 \%$ caffeine-loaded gelatin 
nanoparticles does not significantly change for an incubation time of 24,48 , and $72 \mathrm{~h}$. As the treatment concentration is increased to 25 and $50 \%$, it is observed that the viability rate of L929 cells shows a slight decrease after $48 \mathrm{~h}$ incubation. The viability of L929 cells does not decrease significantly with the treatment of different dilution ratios of caffeine-loaded gelatin nanoparticles.

(a) B16F10 cell

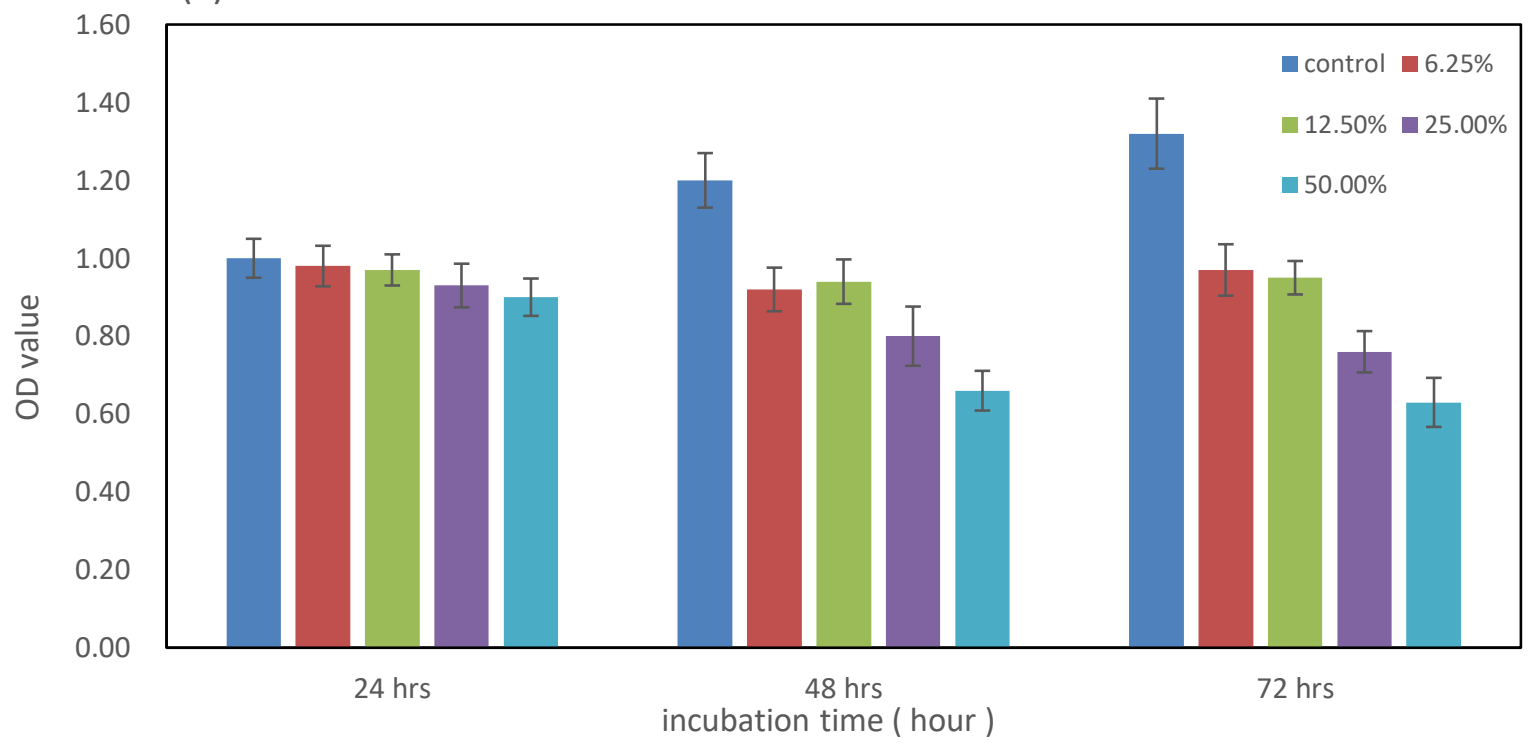

(b) L929 cell

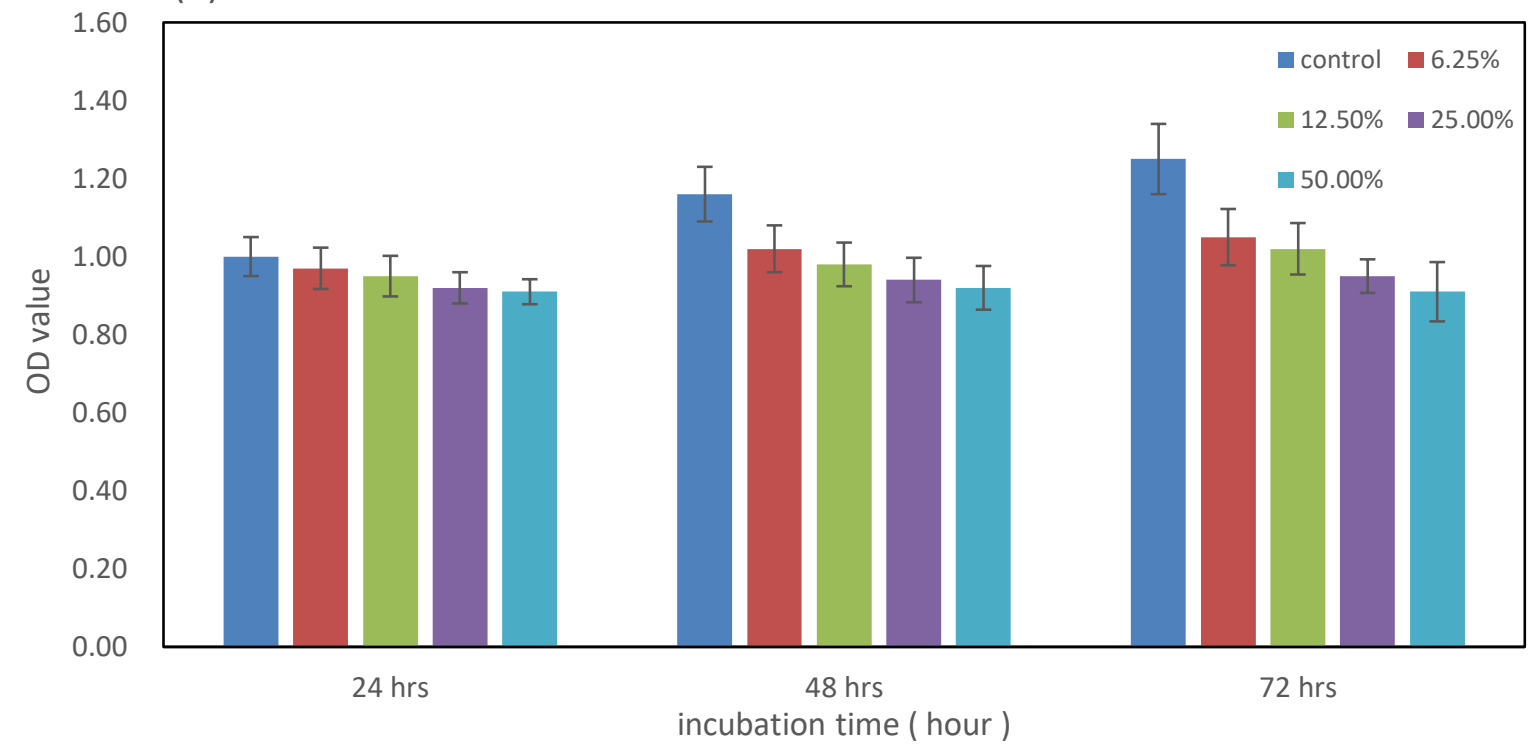

Figure 3. Effects of caffeine-loaded gelatin nanoparticles on cell viability of (a) B16F10 cells and (b) L929 cells. Both cells were treated with different dilution ratios $(0,6.25,12.5,25.0$, and $50.0 \%)$ of caffeine-loaded gelatin nanoparticles for $24 \mathrm{~h}, 48 \mathrm{~h}$, or $72 \mathrm{~h}$.

However, for B16F10 cells, the cell viability decreases rapidly with the treatment of 25 and $50 \%$ caffeine-loaded gelatin nanoparticles after $48 \mathrm{~h}$ incubation. The B16F10 cells are more responsive to treating higher concentrations of caffeine-loaded gelatin nanoparticles than L929 cells. The cell viability data reveal that the B16F10 cells suffer a more significant negative effect on cell response than L929 cells. And also, these viability results indicate that caffeine released from gelatin nanoparticles does have a pernicious effect on B16F10 cancer cells and suppresses the viability and proliferation of B16F10 cancer cells. But, the caffeine 
released from gelatin nanoparticles does not have an obvious harmful effect and significant decreasing change on cell viability for normal cells, L929 cells.

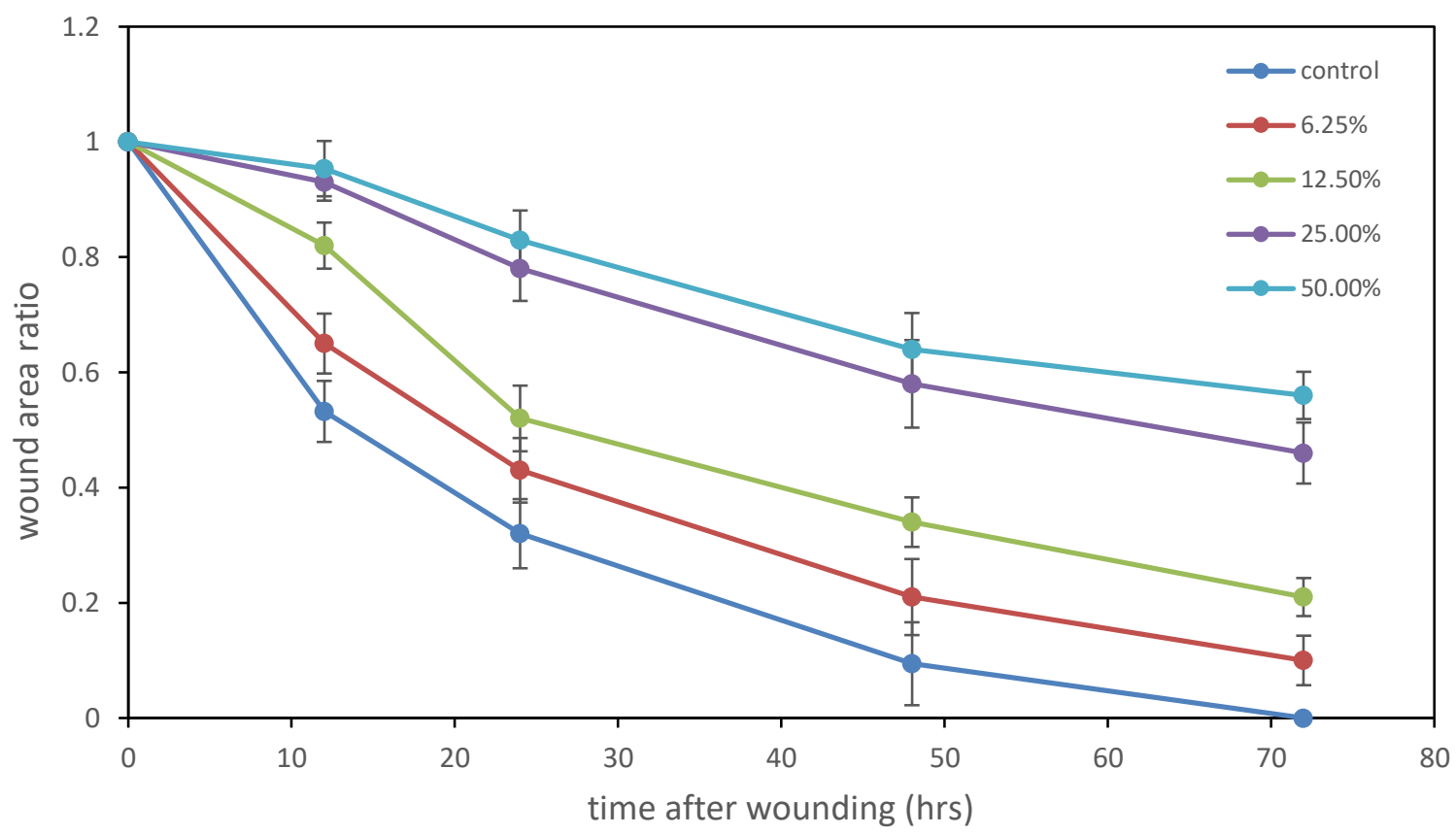

Figure 4. Effects of caffeine-loaded gelatin nanoparticles on cell migration ability of B16F10 cells under different dilution ratios $(0,6.25,12.5,25.0$, and $50.0 \%)$ of gelatin nanoparticles.

The metastasis of cancer cells is accompanied by a series of steps, including migration, invasion, proliferation, and constitution of the blood vessel, etc. In order to verify the effect of caffeine released from gelatin nanoparticles on the migration behavior of melanoma cells, the experiment of migration assay was performed, and the results are shown in Figure 4. The results show that caffeine has a negative effect on the migration and gap closure of melanoma cells. A higher concentration of caffeine-loaded gelatin nanoparticles shows a significant suppressive effect on cell migration. It causes a significant delay in artificial wound gap closure compared with the control group. With treatment of 25 and $50 \%$ caffeine-loaded gelatin nanoparticles, the beginning of wound area recovery is retard until $12 \mathrm{~h}$ later. More than $50 \%$ of the artificial wound area has still not been healed after incubation of $72 \mathrm{~h}$. The wound gap closure rate is slower for all caffein treatment groups than the control group, and the wound recovery rate is significantly slowed down after $48 \mathrm{~h}$. The decreasing wound recovery rate can be attributed to a large amount of caffeine accumulated due to the prolonged-release duration of up to $72 \mathrm{~h}$. The migration assay results indicate that caffeine released from gelatin nanoparticles plays a significant role in regulating the migration of melanoma cells.

It has been reported that cancer therapy exerted its anticancer effect by inducing apoptotic cell death. Signal stimulation through specific cell surface receptors triggers the intracellular molecular cascade and initiates the cell death program, promoting cell apoptosis. During the apoptotic processes of cells, the contact between cells will initially disrupt, and then cell nuclear will condensate and fragment. As a next step to examine the apoptotic cell death, we performed cell apoptosis assay using Hoechst 33342 staining, a fluorescent staining dye for labeling DNA in cell nuclei. Hoechst 33342 is an essay used to distinguish between apoptotic and normal or necrotic cells. Because apoptotic cells will show condensed DNA and fragmented nuclear, normal or necrotic cells will not. The Hoechst 33342 dye stains the condensed chromatin of apoptotic cells more brightly than the chromatin of normal or necrotic 
cells. The staining results of B16F10 and L929 cells treated with caffeine-loaded nanoparticles are shown in Figure 5. No fluorescence is shown in the images in the control group of both B16F10 and L929 cells. For B16F10 cells, the spot number and intensity of fluorescence increase with increasing the incubation time and the concentration of caffeine-loaded gelatin nanoparticles. Contrarily, there is much less fluorescence spot number and intensity appeared in L929 cells than in B16F10 cells. Combined with the cell viability data, it is clearly shown that the B16F10 cells are undergoing the apoptotic processes but not for L929 cells under the treatment of caffeine-loaded gelatin nanoparticles. Both results show that the cell apoptosis is increased by caffeine treatment in a dose-dependent manner compared with the control group. Thus, it's indicated that caffeine released from gelatin nanoparticles could induce the cell apoptosis of B16F10 melanoma cells.

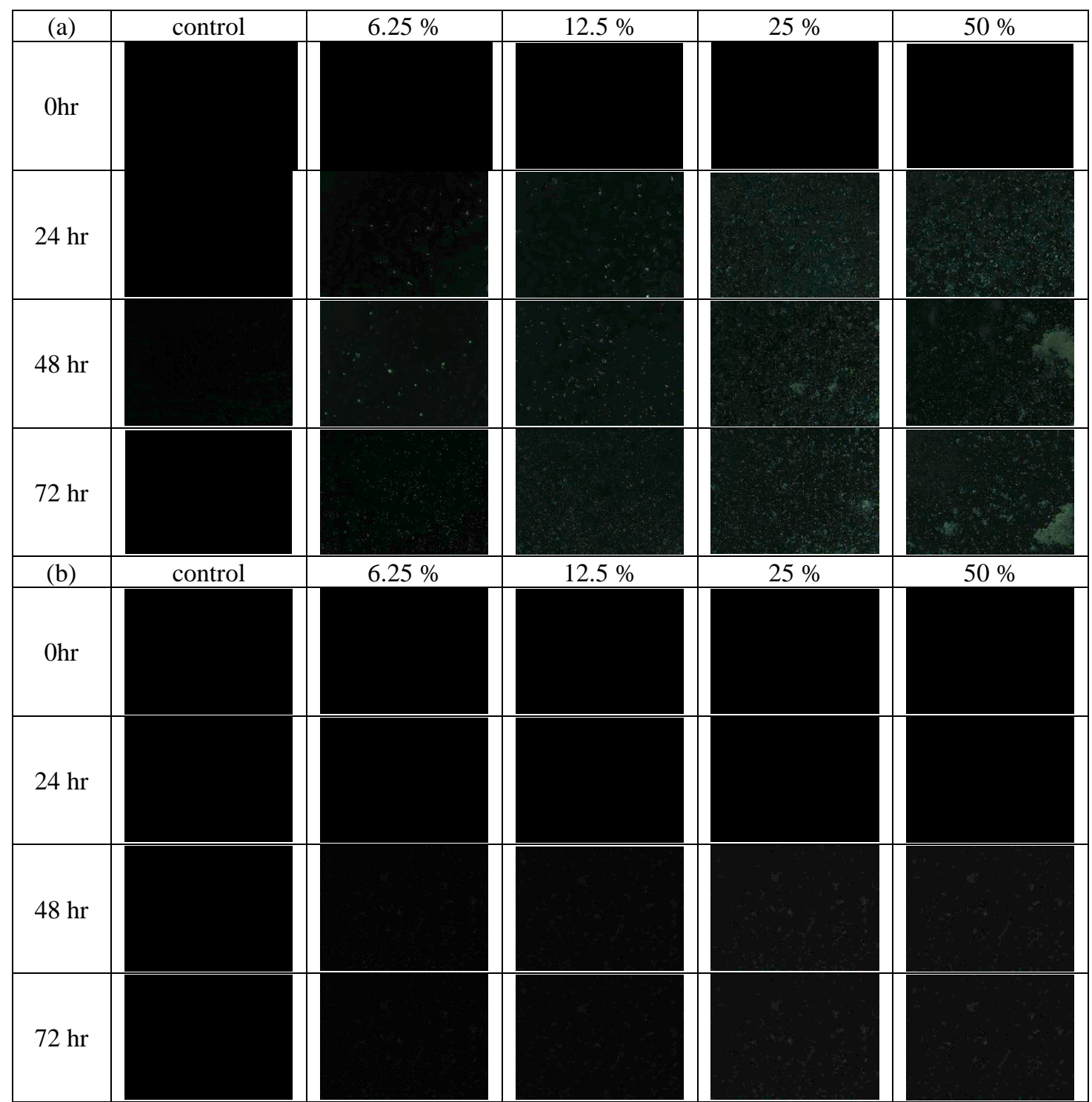

Figure 5. Hoechst 33342 dye staining results of (a) B16F10 and (b) L929 cells under treatment with different dilution ratio $(0,6.25,12.5,25.0$ and $50.0 \%)$ of caffein loaded gelatin nanoparticles for $24 \mathrm{~h}, 48 \mathrm{~h}$, or $72 \mathrm{~h}$.

Alizarin red is used to stain and locate calcium deposits in cell culture or tissues. In the presence of calcium, Alizarin Red binds to the calcium deposits to form a red-colored pigment in cells or tissues. The calcium deposits appearing intracellularly or extracellularly represent that the cells are in processes of dying or death caused by apoptosis. The staining images of Alizarin red for B16F10 and L929 cells with treatment of different dilution ratios of caffeine- 
loaded gelatin nanoparticles are shown in Figure 6. The red-colored stain indicates the happening of calcium deposits. The results show that the amount of appearing calcium deposits in B16F10 cells increases as the release of caffeine from gelatin nanoparticles increases. The amount of red-colored stain in L929 cells is much less than B16F10 cells under the same treatment condition of caffeine-loaded gelatin nanoparticles. These data demonstrate that B16F10 cells will undergo more apoptotic processes than L929 cells under identical caffeine treatment, resulting in more calcium deposits appearing intra or extra cells.

\begin{tabular}{|c|c|c|c|c|c|}
\hline (a) & control & $6.25 \%$ & $12.5 \%$ & $25 \%$ & $50 \%$ \\
\hline $\mathrm{Ohr}$ & & & & & \\
\hline $24 \mathrm{hr}$ & & & & & \\
\hline $48 \mathrm{hr}$ & & & & & \\
\hline $72 \mathrm{hr}$ & & & & & \\
\hline (b) & control & $6.25 \%$ & $12.5 \%$ & $25 \%$ & $50 \%$ \\
\hline Ohr & & & & & \\
\hline $24 \mathrm{hr}$ & & & & & \\
\hline $48 \mathrm{hr}$ & & & & & \\
\hline $72 \mathrm{hr}$ & & & & & \\
\hline
\end{tabular}

Figure 6. Alizarin red staining results of (a) B16F10 and (b) L929 cells under treatment with different dilution ratio $(0,6.25,12.5,25.0$ and $50.0 \%)$ of caffein loaded gelatin nanoparticles for $24 \mathrm{~h}, 48 \mathrm{~h}$, or $72 \mathrm{~h}$.

Many pieces of research have shown the anticancer effects of caffeine in various cancer cells. For example, caffeine can induce apoptosis in human neuroblastoma cells and human lung tumor cells [37, 38] and decrease human leukemia U937 cells [39]. Based on previous research, caffeine might have anticancer effects on melanoma cells. Therefore, a caffein release system based on biodegradable gelatin nanoparticles has been designed, and then the effects on melanoma cell viability, migration, and apoptosis have been investigated. Similar to previous researches, the application of caffeine-loaded gelatin nanoparticles on melanoma cells showed an anti-proliferation effect with a dose and time manner. Moreover, significant inhibition of migration and induction of apoptosis on melanoma cells were also observed. 


\section{Conclusions}

This paper investigated the effects of caffeine released from biodegradable gelatin nanoparticles on melanoma B16F10 cells and fibroblast L929 cells. The data from cell assays demonstrate that caffein inhibits cell proliferation, viability, and migration and induces apoptotic death of melanoma B16 cells. But for fibroblast L929 cells, the cell assay results show much less cytotoxicity of caffeine than melanoma B16 cells. These results prove that caffeine-loaded gelatin nanoparticles effectively and selectively induce cell apoptosis of cancer melanoma B16F10ells without causing harmful effects on normal fibroblast L929 cells and show that caffein might offer the alternative way for safe and effective clinical therapy of melanoma.

\section{Funding}

This research was funded by the Ministry of Science and Technology of Taiwan, grant number MOST 110-2221-E-130-013.

\section{Acknowledgments}

The authors would like to express their gratitude to all the lab staff from the Department of Biomedical Engineering, Ming Chuan University, for assisting with the project.

\section{Conflicts of Interest}

The authors declare no conflict of interest.

\section{References}

1. Siegel, R.L.; Miller, K.D.; Jemal, A. Cancer statistics, 2020. CA: A Cancer J for Clin 2020, 70, 7-30, https://doi.org/10.3322/caac.21590.

2. Sung, H.; Ferlay, J.; Siegel, R.L.; Laversanne, M.; Soerjomataram, I.; Jemal, A.; Bray, F. Global Cancer Statistics 2020: GLOBOCAN Estimates of Incidence and Mortality Worldwide for 36 Cancers in 185 Countries. CA: A Cancer J for Clin. 2021 , 71, 209-249, https://doi.org/10.3322/caac.21660.

3. Liguoro, D.; Fattore, L.; Mancini, R.; Ciliberto G. Drug tolerance to target therapy in melanoma revealed at single cell level: What next?, Biochim Biophys Acta - Rev on Cancer. 2020, 1874, 188440, https://doi.org/10.1016/j.bbcan.2020.188440.

4. Bell, C.C.; Gilan, O. Principles and mechanisms of non-genetic resistance in cancer. Br J Cancer. 2020, 122 , 465-472, https://doi.org/10.1038/s41416-019-0648-6

5. Orgaz, J.L.; Crosas-Molist, E.; Sadok, A.; Perdrix-Rosell, A.; Maiques, O.; Rodriguez-Hernandez, I.; Monger, J.; Mele, S.; Georgouli, M.; Bridgeman, V.; Karagiannis, P.; Lee, R.; Pandya, P.; Boehme, L.; Wallberg, F.; Tape, C.; Karagiannis, S.N.; Malanchi, I.; Sanz-Moreno, V. Myosin II Reactivation and Cytoskeletal Remodeling as a Hallmark and a Vulnerability in Melanoma Therapy Resistance. Cancer Cell 2020, 37, P85-103.E9, https://doi.org/10.1016/j.ccell.2019.12.003.

6. Ahn, H.J.; Kim, K.I.; Kim, G.; Moon, E.; Yang, S.S.; Lee, J.S. Atmospheric-Pressure Plasma Jet Induces Apoptosis Involving Mitochondria via Generation of Free Radicals. PLOS ONE 2011, 6, e28154, https://doi.org/10.1371/journal.pone.0028154.

7. Yan, X.; Xiong, Z.; Zou, F.; Zhao, S.; Lu, X.; Yang, G.; He, G.; Ostrikov, K. Plasma-induced death of HepG2 cancer cells: Intracellular effects of reactive species. Plasma Process. Polym. 2012, 9, 59-66, https://doi.org/10.1002/ppap.201100031.

8. Kim, G.C.; Kim, G.J.; Park, S.R.; Jeon, S.M.; Seo, H.J.; Iza, F.; Lee, J.K. Air plasma coupled with antibodyconjugated nanoparticles: a new weapon against cancer. J. Phys. D: Appl. Phys. 2008, 42, 032005, https://doi.org/10.1088/0022-3727/42/3/032005. 
9. Lee, H.J.; Shon, C.H.; Kim, Y.S.; Kim, S.; Kim, G.C.; Kong, G. Degradation of adhesion molecules of G361 melanoma cells by a nonthermal atmospheric pressure microplasma. New J. Phys. 2009, 11, 115026, http://dx.doi.org/10.1088/1367-2630/11/11/115026.

10. Arndt, S.; Wacker, E.; Li, Y.F.; Shimizu, T.; Thomas, H.M.; Morfill, G.E.; Karrer, S.; Zimmermann, J.L.; Bosserhoff, A.K. Cold atmospheric plasma, a new strategy to induce senescence in melanoma cells. Exp. Dermatol. 2013, 22, 284-289, https://doi.org/10.1111/exd.12127.

11. Tanaka, H.; Mizuno, M.; Ishikawa, K.; Nakamura, K.; Kajiyama, H.; Kano, H.; Kikkawa, F.; Hori, M. Plasma-Activated Medium Selectively Kills Glioblastoma Brain Tumor Cells by Down-Regulating a Survival Signaling Molecule, AKT Kinase. Plasma Med. 2011, 1, 265-277, https://doi.org/10.1615/PlasmaMed.2012006275.

12. Cheng, X.; Murphy, W.; Recek, N.; Yan, D.; Cvelbar, U.; Vesel, A.; Mozetič, M.; Canady, J; Keidar, M.; Sherman, J.H. Synergistic effect of gold nanoparticles and cold plasma on glioblastoma cancer therapy. $J$. Phys. D: Appl. Phys. 2014, 47, 335402, https://doi.org/10.1088/0022-3727/47/33/335402.

13. Thiyagarajan, M.; Waldbeser, L.; Whitmill, A. THP-1 leukemia cancer treatment using a portable plasma device. Stud. Health Technol. Inform. 2012, 173, 515-517, https://doi.org/10.3233/978-1-61499-022-2-515.

14. Barekzi, N.; Laroussi, M. Dose-dependent killing of leukemia cells by low-temperature plasma. J. Phys. D: Appl. Phys. 2012, 45, 422002, https://doi.org/10.1088/0022-3727/45/42/422002.

15. Keidar, M. Plasma for cancer treatment. Plasma Sources Sci. Technol. 2015, 24, 033001, https://doi.org/10.1088/0963-0252/24/3/033001.

16. Balzer, J.; Demir, E.; Kogelheide, F.; Fuchs, P.C.; Stapelmann, K.; Opländer, C. Cold atmospheric plasma (CAP) differently affects migration and differentiation of keratinocytes via hydrogen peroxide and nitric oxide-related products. Clin. Plasma Med. 2019, 13, 1-8, https://doi.org/10.1016/j.cpme.2018.11.001.

17. Keidar, M.; Walk, R.; Shashurin, A.; Srinivasan, P.; Sandler, A.; Dasgupta, S.; Ravi, R.; Guerrero-Preston, R.; Trink, B. Cold plasma selectivity and the possibility of a paradigm shift in cancer therapy. Br. J. Cancer 2011, 105, 1295-1301, https://doi.org/10.1038/bjc.2011.386.

18. Kim, J.Y.; Ballato, J.; Foy, P.R.; Hawkins, T., Wei, Y., Li, J.; Kim, S. Apoptosis of lung carcinoma cells induced by a flexible optical fiber-based cold microplasma. Biosens. Bioelectron. 2011, 28, 333-338, https://doi.org/10.1016/j.bios.2011.07.039.

19. Fridman, G.; Friedman, G.; Gutsol, A.; Shekhter, A.B.; Vasilets, V.N.; Fridman, A. Applied plasma medicine. Plasma Process Polym 2008, 5, 503-533, https://doi.org/10.1002/ppap.200700154.

20. Kalghatgi, S.; Kelly, C.M.; Cerchar, E.; Torabi, B.; Alekseev, O.; Fridman, A.; Friedman, G. AzizkhanClifford, J. Effects of nonthermal plasma on mammalian cells. PLoS One 2011, 6, e16270, https://doi.org/10.1371/journal.pone.0016270.

21. Hoffmann, C.; Berganza, C.; Zhang, J. Cold atmospheric plasma: methods of production and application in dentistry and oncology. Medical Gas Res. 2013, 3, 21, https://doi.org/10.1186/2045-9912-3-21.

22. Braný, D.; Dvorská, D.; Halašová, E.; Škovierová, H. Cold Atmospheric Plasma: A Powerful Tool for Modern Medicine. Int. J. Mol. Sci. 2020, 21, 2932, https://doi.org/10.3390/ijms21082932.

23. Zhao, S.; Xiong, Z.; Mao, X.; Meng, D.; Lei, Q.; Li, Y.; Deng, P.; Chen, M.; Tu, M.; Lu, X.; Yang, G.; He, G. Atmospheric pressure room temperature plasma jets facilitate oxidative and nitrative stress and lead to endoplasmic reticulum stress dependent apoptosis in HepG2 cells. PloS one 2013, 8, e73665, https://doi.org/10.1371/journal.pone.0073665.

24. Kaushik, N.K., Kaushik, N., Park, D.; Choi, E.H. Altered Antioxidant System Stimulates Dielectric Barrier Discharge Plasma-Induced Cell Death for Solid Tumor Cell Treatment. PloS one 2014, 9, e103349, https://doi.org/10.1371/journal.pone.0103349.

25. Köritzer, J.; Boxhammer, V.; Schäfer, A.; Shimizu, T.; Klämpfl, T.G.; Li, Y.F.; Welz, C.; Schwenk-Zieger, S.; Morfill, G.E.; Zimmermann, J.L.; Schlegel, J. Restoration of sensitivity in chemo-resistant glioma cells by cold atmospheric plasma. PloS one 2013, 8, e64498, https://doi.org/10.1371/journal.pone.0064498.

26. Volotskova, O.; Hawley, T. S.; Stepp, M. A.; Keidar, M. Targeting the cancer cell cycle by cold atmospheric plasma. Sci. Rep. 2012, 2, 636, https://doi.org/10.1038/srep00636.

27. Partecke, L.; Evert, K.; Haugk, J.; Doering, F.; Normann, L.; Diedrich, S.; Weiss, F.; Evert, M.; Huebner, N.; Guenther, C.; Heidecke, C.; Kramer, A.; Bussiahn, R.; Weltmann, K.; Pati, O.; Bender, C.; Bernstorff, W.V. Tissue Tolerable Plasma (TTP) induces apoptosis in pancreatic cancer cells in vitro and in vivo. BMC Cancer 2012, 12, 473, https://doi.org/10.1186/1471-2407-12-473.

28. Chen, Z.; Cheng, X.; Lin, L.; Keidar, M. Cold atmospheric plasma discharged in water and its potential use in cancer therapy. J. Phys. D: Appl. Phys. 2017, 50, 015208, https://doi.org/10.1088/1361-6463/50/1/015208. 
29. Wrześniok, D.; Rzepka, Z.; Respondek, M.; Beberok, A.; Rok, J.; Szczepanik, K.; Buszman, E. Caffeine modulates growth and vitality of human melanotic COLO829 and amelanotic C32 melanoma cells: Preliminary findings. Food Chem Toxicol. 2018, 120, 566-570, https://doi.org/10.1016/j.fct.2018.07.049.

30. Wang, Z.; Zhang, L.; Wan, Z.; He, Y.; Huang, H.; Xiang, H.; Wu, X.; Zhang, K.; Liu, Y.; Goodin, S.; Du, Z.; Zheng, X. Atorvastatin and Caffeine in Combination Regulates Apoptosis, Migration, Invasion and Tumorspheres of Prostate Cancer Cells. Pathol. Oncol. Res. 2020, 26, 209-216, https://doi.org/10.1007/s12253-018-0415-7

31. Machado, K. L.; Marinello, P. C.; Silva, T. N. X.; Silva, C. F. N.; Luiz, R. C.; Cecchini, R.; Cecchini, A. L. (2021) Oxidative Stress in Caffeine Action on the Proliferation and Death of Human Breast Cancer Cells MCF-7 and MDA-MB-231, Nutrition and Cancer 2021, 73, 1378-1388, https://doi.org/ 10.1080/01635581.2020.1795693

32. Tej, G.N.V.C.; Neogi, K.; Verma, S.S.; Gupta, S.C.; Nayak, P.K. Caffeine-enhanced antitumor immune response through decreased expression of PD1 on infiltrated cytotoxic T lymphocytes, Eur. J. Pharmacol. 2019, 859, 172538, https://doi.org/10.1016/j.ejphar.2019.172538.

33. Tabolacci, C.; Cordella, M.; Rossi, S.; Bonaccio, M.; Eramo, A.; Mischiati, C.; Beninati, S.; Iacoviello, L.; Facchiano, A.; Facchiano, F. Targeting Melanoma-Initiating Cells by Caffeine: In Silico and In Vitro Approaches. Molecules 2021, 26, 3619. https://doi.org/10.3390/molecules26123619.

34. Yang, H.; Rouse, J.; Lukes, L.; Lancaster, M.; Veenstra, T.; Zhou, M.; Shi, Y.; Park, Y.G.; Hunter, K. Caffeine suppresses metastasis in a transgenic mouse model: a prototype molecule for prophylaxis of metastasis. Clin. Exp. Metastasis 2005, 21, 719-735, https://doi.org/10.1007/s10585-004-8251-4.

35. Li, L.; Zhang, W.; Huang, M.; Li, J.; Chen, J.; Zhou, M.; He, J. Preparation of gelatin/genipin nanofibrous membrane for tympanic member repair. J. Biomater. Sci. Polym. Ed. 2018, 29, 2154-2167, https://doi.org/10.1080/09205063.2018.1528519.

36. Coester, C. J.; Langer, K.; Von Briesen, H.; Kreuter, J. Gelatin nanoparticles by two step desolvation a new preparation method, surface modifications and cell uptake, J. Microencapsulation 2000, 17, 187-193, https://doi.org/10.1080/026520400288427.

37. Tonkaboni, A.; Lotfibakhshaiesh, N.; Danesh, P.; Tajerian, R.; Ziaei, H. Evaluation of Inhibitory Effects of Caffeine on Human Carcinoma Cells, Nutrition and Cancer 2021, 73, 1998-2002, https://doi.org/ 10.1080/01635581.2020.1819344.

38. Qi, W.; Qiao, D.; Martinez, J.D. Caffeine induces TP53-independent $\mathrm{G}_{1}$-phase arrest and apoptosis in human lung tumor cells in a dose-dependent manner. Radiat Res. 2002, 157, 166-174, https://doi.org/10.1667/00337587(2002)157[0166: citigp]2.0.co;2.

39. Liu, W.H.; Chang, L.S. Caffeine induces matrix metalloproteinase-2 (MMP-2) and MMP-9 down-regulation in human leukemia U937 cells via $\mathrm{Ca}^{2+} / \mathrm{ROS}$-mediated suppression of ERK/c-fos pathway and activation of p38 MAPK/c-jun pathway. J. Cell. Physiol. 2010, 224, 775-785, https://doi.org/10.1002/jcp. 22180. 